\title{
EKSPLORASI PEWARNAAN BEBERAPA JENIS KAIN MENGGUNAKAN PEWARNA ALAMI JOLAWE DAN SECANG DENGAN FIKSASI TAWAS, BAKING SODA DAN JERUK NIPIS
}

\author{
Dita Andansari \\ Staf Pengajar Program Studi Desain Produk, Jurusan Desain \\ Politeknik Negeri Samarinda \\ Email:ditaandansari@yahoo.com \\ Mardhiyah Nadir \\ Staf Pengajar Jurusan Teknik Kimia \\ Politeknik Negeri Samarinda \\ Email: mardhiyahnadir@yahoo.co.id
}

\begin{abstract}
ABSTRAK
Industri kreatif di Indonesia rata-rata memberikan kontribusi PDB sebesar 6,3 persen dari total PDB Nasional dengan nilai Rp. 104,6 triliun pada tahun 2002-2006. PDB industri kreatif saat ini masih didominasi oleh kelompok fesyen, kerajinan, periklanan dan desain. Menurut Menperin MS Hidayat, dari tujuh sektor industri kreatifyang ada, sektor andalan yang bisa terus tumbuh dan meningkatkan ekspor adalah industri fashion dan kerajinan serta komputer dan piranti lunak. Lebih jauh, ekspor industri fashion dan kerajinan mencapai 13 miliar dolar AS per tahun. Dengan peluang ekspor yang besar, maka kerajinan di bidang fashion di Kalimantan Timur seharusnya lebih dikembangkan. Kerajinan khas di Kalimantan Timur terdiri dari berbagai macam produk, baik batik, tenun, kerajinan kayu dan kerajinan lainnya. Di bidang fashion khususnya busana dan pelengkap busana yang banyak dibuat oleh UKM di Kalimantan Timur diantaranya adalah dari bahan batik dan tenun. Belum ada usaha untuk mengembangkan jenis bahan dan teknik yang lain yang bisa dijadikan sebagai diversifikasi produk kerajinan. Salah satu teknik yang bisa dikembangkan di Kalimantan Timur adalah teknik pewarnaan jumputan atau tie dye. Selain kurangnya diversifikasi dari sudut teknik pewarnaan, penggunaan jenis bahan, penggunaan pewarna alami belum banyak digunakan. Sehingga dilakukan penelitian Eksplorasi Pewarnaan Beberap Jenis Kain Menggunakan Pewarna Alami Jolawe dan Secang dengan Fiksasi Tawas, jeruk nipis dan baking soda. Metode yang dilakukan adalah eksperimen dengan analisis deskriptif kualitatif. Hasil yang didapat adalah pewarnaan pada jenis kain katun prima, hero/eru, mori, katun primis, mori (hulala), titoron, katun Jepang halus (Roberto) dan katun Jepang sedang (Kenter), penggunaan fiksator tawas adalah yang paling menghasilkan penyerapan warna yang baik, untuk pewarna alami secang, penggunaan fiksator jeruk nipis dan baking soda kurang direkomendasikan kecuali memerlukan tampilan merah muda ke arah kecoklatan untuk fiksator jeruk nipis dan merah muda dengan value rendah untuk fiksator baking soda dan penggunaan pewarna alami jolawe, untuk penggunaan fiksator jeruk nipis dan baking soda tidak disarankan.
\end{abstract}

Kata kunci: pewarnaan, jolawe, secang, tawas, jeruk nipis,baking soda 


\section{PENDAhULUAN}

Salah satu penyumbang ekspor Indonesia adalah industri kreatif. Industri kreatif di Indonesia rata-rata memberikan kontribusi PDB sebesar 6,3 persen dari total PDB Nasional dengan nilai Rp. 104,6 triliun pada tahun 2002-2006. (elib.pdii.lipi.go.id) PDB industri kreatif menduduki peringkat ke-7 dari 10 lapangan usaha utama yang ada di Indonesia. PDB industri kreatif saat ini masih didominasi oleh kelompok fesyen, kerajinan, periklanan dan desain. Pasar ekspor Indonesia masih didominasi oleh produk-produk bahan baku alam, masih berorientasi hulu, sementara MEA berbicara mengenai industri hilir dan competitiveness. Dengan demikian maka peluang ekspor ekonomi kreatif masih besar diantaranya produk kerajinan. Menurut Djailani (Kepala Dinas Perindustrian, Perdagangan, Koperasi dan UMKM Kaltim, 2014) bahwa salah satu komoditi yang terus dikembangkan dan diberi dukungan permodalan usaha yakni produk kerajinan tangan agar menjadi komoditi ekspor. Hal ini didukung juga dengan hasil survey yang dilakukan pemerintah, bahwa sekitar 99,9\% dunia usaha di Indonesia masuk ke dalam kategori usaha mikro dan kecil. Usaha mikro dan kecil menyerap 97\% dari seluruh tenaga kerja nasional dan berkontribusi tidak kurang dari $60 \%$ product domestic bruto (PDB).

Menurut Menperin MS Hidayat, dari tujuh sektor industri kreatif yang ada, sektor andalan yang bisa terus tumbuh dan meningkatkan ekspor adalah industri fashion dan kerajinan serta komputer dan piranti lunak. Nilai tambah yang dihasilkan industri fashion dan kerajinan sebesar $44,3 \%$ dan $24,8 \%$. Kontribusi penyerapan tenaga kerja mencapai 54,35 dan $31,13 \%$ dari total penyerapan di industri kreatif. Lebih jauh, ekspor industri fashion dan kerajinan mencapai 13 miliar dolar AS per tahun. Dengan peluang ekspor yang besar, maka kerajinan di bidang fashion di Kalimantan Timur seharusnya lebih dikembangkan. Menurut Riana, dalam penelitian
Vol. 4, No. 2, April 2017

Pengembangan Industri Fesyen Sebagai Industri Kreatif Unggulan Untuk Mendorong Pembangunan Ekonomi Indonesia, menyimpulkan bahwa Industri fesyen menjadi industri potensial dan unggulan bagi penyumbang PDB Indonesia dan sebagai penyedia lapangan kerja yang potensial sebagai solusi mengatasi jumlah pengangguran di Indonesia.

Kerajinan khas di Kalimantan Timur terdiri dari berbagai macam produk, baik batik, tenun, kerajinan kayu dan kerajinan lainnya. Di bidang fashion khususnya busana dan pelengkap busana yang banyak dibuat oleh UKM di Kalimantan Timur diantaranya adalah dari bahan batik dan tenun. Belum ada usaha untuk mengembangkan jenis bahan dan teknik yang lain yang bisa dijadikan sebagai diversifikasi produk kerajinan. Salah satu teknik yang bisa dikembangkan di Kalimantan Timur adalah teknik pewarnaan jumputan atau tie dye. Selain mudah dikerjakan, proses pembuatan teknik jumputan juga membutuhkan biaya yang relative murah. Menurut Herdiana dan Khoe (2015) dalam penelitian The Dye Techniques and Material Variation menyimpulkan bahwa 1. Eksperimen pewarnaan tie dye dengan bahan jersey dengan teknik ikat pada botol, hasil yang didapat menyerap warna dengan sempurna dan cepat, memberikan efek garis menyerupai kain tenun, pemberian satu warna menimbulkan efek pewarnaan gradasi dan penyerapan warnanya sangat pekat. 2 . Eksperimen dengan bahan satin dengan teknik ikat pada botol, hasil yang didapat menyerap warna dengan sempurna dan cepat, motif tampak baur sehingga corak tie dye pada kain tidak terlalu terlihat, pemberian lebih dari satu warna tidak terlihat perbedaan. 3. Eksperimen dengan bahan satin dengan teknik celup, hasil yang didapat lebih baik diterapkan pada kain satin dibandingkan dengan teknik semprot dan ikat sebelumnya, memberikan efek mengkilap karena tidak semua bagian kain terkena 
Dita Andansari, Mardhiyah Nadir, Eksplorasi Pewarnaan Beberapa Jenis Kain Menggunakan Pewarnaan Alami Jolawe dan Secang Dengan Fiksasi Tawas, Baking Soda dan Jeruk Nipis

warna sehingga efek kilap dari kain satin sendiri akan muncul. 4. Eksperimen dengan bahan jeans tebal dengan bleaching dan teknik punter, hasil yang didapat bercak putih yang dihasilkan dari bleaching sudah cukup menghasilkan pola yang cantik, relatif mudah untuk cara pembuatannya, kain jeans yang tebal lebih susah menyerap cairan pemutih. 5. Eksperimen dengan bahan jeans tipis dengan bleaching dan teknik ikat pada botol, hasil yang didapat bercak putih yang dihasilkan dari bleaching sudah cukup menghasilkan pola yang cantik, teknik relatif mudah. 6. Eksperimen dengan bahan katun prima, hasil yang didapat penggunaan macam warna yang banyak akan mengakibatkan warna berbaur karena jenis katun prima yang gampang menyerap.

Dunia fashion tidak terlepas dari kain atau tekstil (Akriliyati, 2016), pemilihan karakter kain yang tepat akan membuat rancangan seseorang menjadi khas dan sesuai dengan pemakainya. Pada garis besarnya, serat pembentuk kain terbagi dua, serat natural dan serat sintetis. Serat natural yaitu serat alami yang diambil dari tanaman. Seperti katun, linen, rami, serat nanas, serat pisang dan rayon. Sedangkan dari hewan seperti wol, merino, "chasmere", mohair, angora, sutra. Serat berasal dari mineral, seperti benang emas, benang perak, silikon. Sementara serta sintetis dibuat dari minyak bumi, dibuat untuk menggantikan kain-kain dari serat alam atau natural yang kian lama kian tinggi harganya. Seperti polyester, nylon, akrilik.

Selain kain, yang paling penting pada proses pewarnaan adalah zat warna itu sendiri. Jenis pewarna dibedakan menjadi 2 bagian besar yaitu pewarna alami dan pewarna sintetis. Pewarna alami lebih aman digunakan karena tidak mengandung zat kimia yang dapat mengakibatkan reaksi berbeda terhadap penggunanya. Dengan latar belakang di atas, maka dilakukan penelitian Eksplorasi Pewarnaan Beberap Jenis Kain Menggunakan Pewarna Alami Jolawe dan 34
Secang dengan Fiksasi Tawas, jeruk nipis dan baking soda.

\section{METODE}

Metode dalam penelitian ini adalah eksperimen dengan analisisnya adalah deskriptif kualitatif, dimana penelitian deskriptif kualitratif adalah penelitian yang bertujuan untuk membuat deskripsi, gambaran mengenai fakta-fakta, sifat-sifat serta hubungan antar fenomena yang diteliti (Sutopo, 2002). Pewarnaan pada beberapa kain ini mengunakan 2 (dua) jenis pewarna yaitu secang untuk mewakili warna dengan kesan hangat (impuls tinggi) yaitu merah muda kejinggaan dan jolawe untuk mewakili warna dengan kesan sejuk (impuls rendah) yaitu hijau. Proses fiksasinya menggunakan 3 (tiga) jenis yaitu tawas, baking soda dan jeruk nipis. Jenis kain yang digunakan adalah kain yang mengandung serat alami yaitu katun ( katun proma, mori, katun primis dan katun Jepang) maupun yang mengandung serat alami campuran sintetis (hero/eru dan titoron). Setelah dilakukan pewarnaan pada beberapa jenis kain, maka dilakukan analisis deskripsi dengan melihat tampilan warna dihasilkan oleh kedua jenis pewarna.

\section{PEMBAHASAN}

Tahapan pewarnaan dimulai dengan proses mordanting, proses pencelupan warna dan proses fiksasi. Proses mordanting adalah proses penghilangan zat-zat kimia yang menempel pada kain sehingga tingkat menyerapan menjadi maksimal. Proses pencelupan adalah proses pencelupan ke dalam zat warna. Serta Fiksasi adalah proses penguncian warna sehingga warna terikat lebih sempurna terhadap kain.

\section{Proses Mordanting}

Proses mordanting dapat dilakukan dengan berbagai cara, salah satu diantaranya adalah dengan merendam kain ke larutan air yang sudah dicampur dengan deterjen. Proses perendaman ini dilakukan selama 24 jam. Setelah perendaman, maka dilakukan 


\section{Fratif}

pembilasan dengan air berkali-kali sampai tidak ada lagi deterjen yang menempel.

\section{Proses Pewarnaan}

Proses pewarnaan dilakukan dengan tahapan yaitu:

1. Perebusan bahan pewarna alam yang dicampur dengan air. Komposisi zat warna dengan air dapat disesuaikan sesuai dengan kebutuhan.

Pada penelitian ini, direbus zat alam dari kayu secang dan jolawe dengan perbandingan 250gram zat warna dengan 6 liter air.

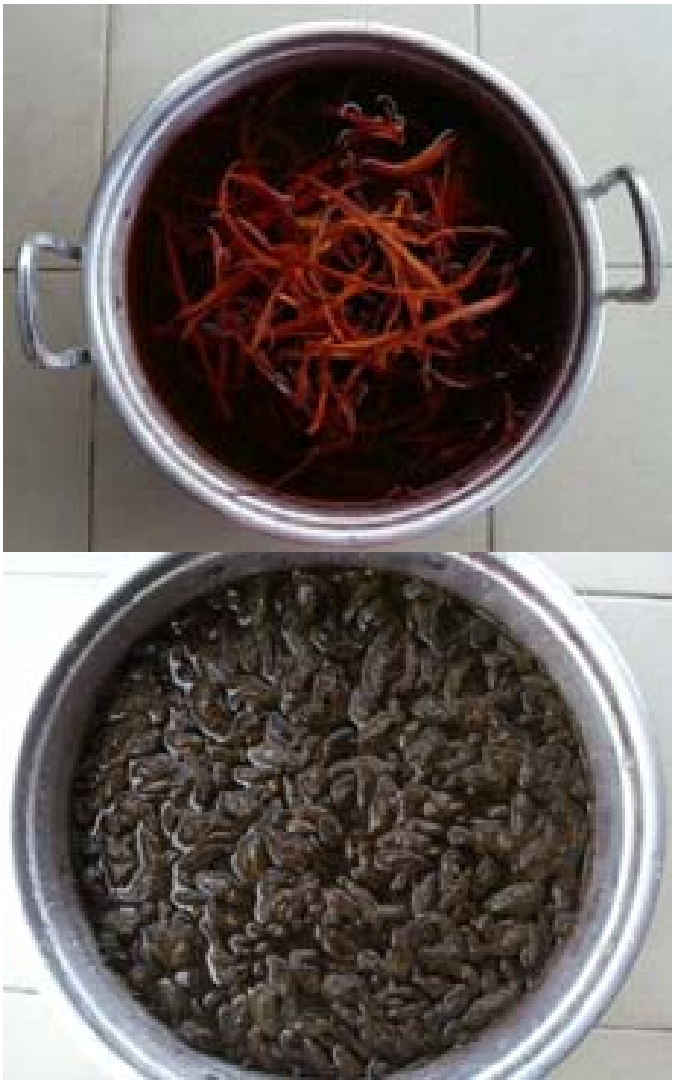

Gambar 1. Proses perebusan bahan pewarna
Vol. 4, No. 2, April 2017

2. Setelah proses perebusan zat warna, maka dilakukan proses pencelupan zat warna. Masing-masing jenis kain dicelupkan baik di pewarna secang maupun di pewarna jolawe.

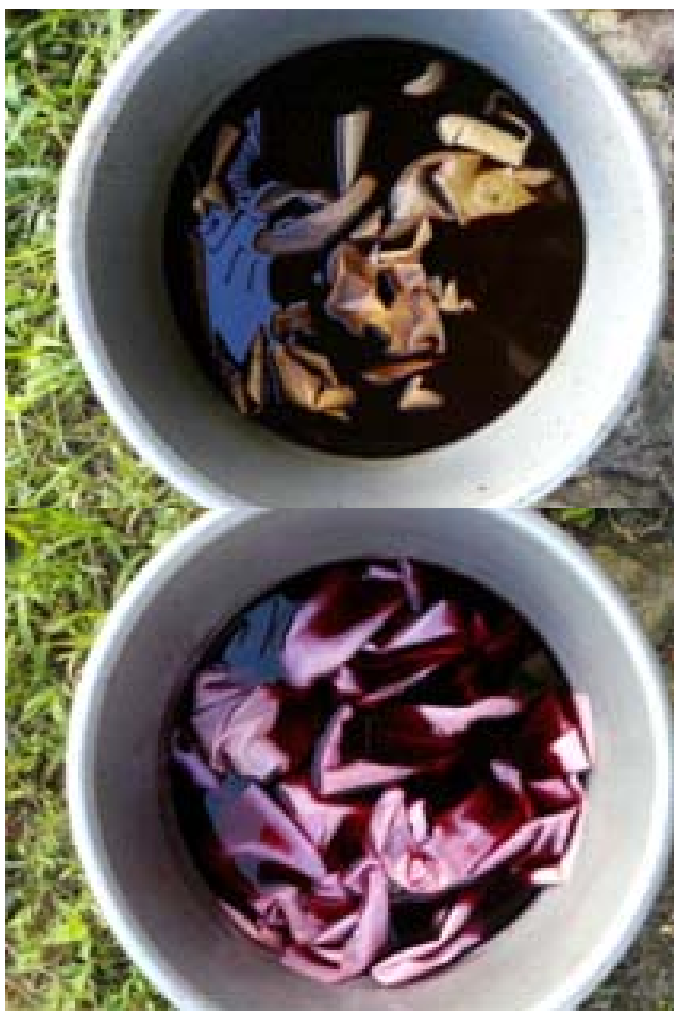

Gambar 2. Proses pencelupan zat pewarna

3. Setelah proses pewarnaan selesai, maka dilakukan penjemuran kain

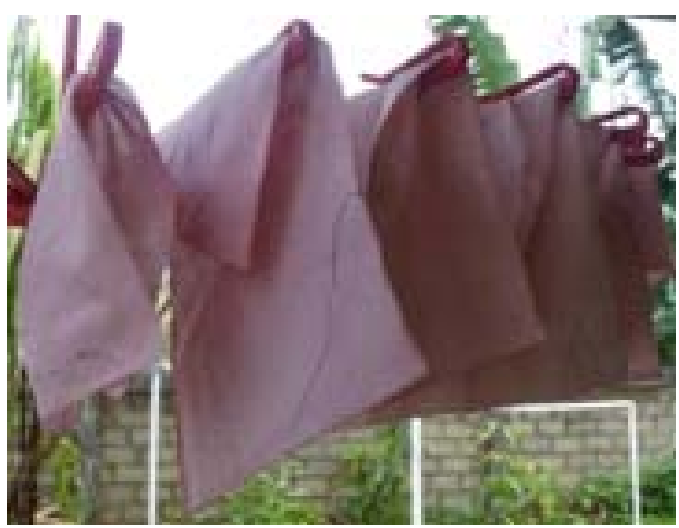

Gambar 3. Proses penjemuran 
Dita Andansari, Mardhiyah Nadir, Eksplorasi Pewarnaan Beberapa Jenis Kain Menggunakan Pewarnaan Alami Jolawe dan Secang Dengan Fiksasi Tawas, Baking Soda dan Jeruk Nipis

\section{Proses Fiksasi}

Setelah kain kering maka bisa dilakukan proses fiksasi. Tahapan fiksasi adalah sebagai berikut :

\section{Persiapan zat fiksasi}

Fiksasi dipersiapkan diantaranya adalah tawas untuk mewakili netral, baking soda untuk mewakili fiksasi basa dan jeruk untuk mewakili fiksasi asam. Untuk komposisinya adalah 70 gram tawas/baking soda/jeruk nipis dengan air 1 liter.

2. Pencelupan ke zat fiksasi

Tahapan selanjutnya adalah pencelupan kain ke masing - masing zat fiksasi.

\section{Pembilasan}

Setelah proses fiksasi, maka kain ditiriskan sampai air tidak menetes baru kemudian dibilas dengan air biasa.

4. Penjemuran

Setelah dibilas, tahapan akhir adalah proses penjemuran.

\section{Hasil}

Setelah kain kering, maka dapat dilakukan pengamatan terhadap warna yang dihasilkan dari proses eksperimen. Berikut hasil warna yang dihasilkan oleh pewarna secang dan jolawe dengan fiksator tawas, baking soda dan jeruk nipis.

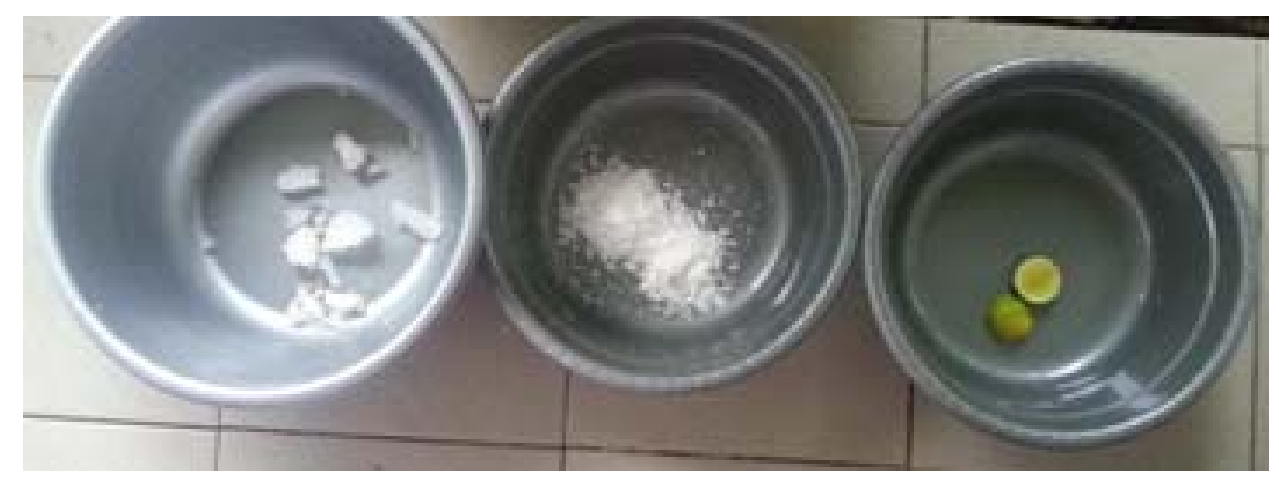

Gambar 4. Proses penjemuran

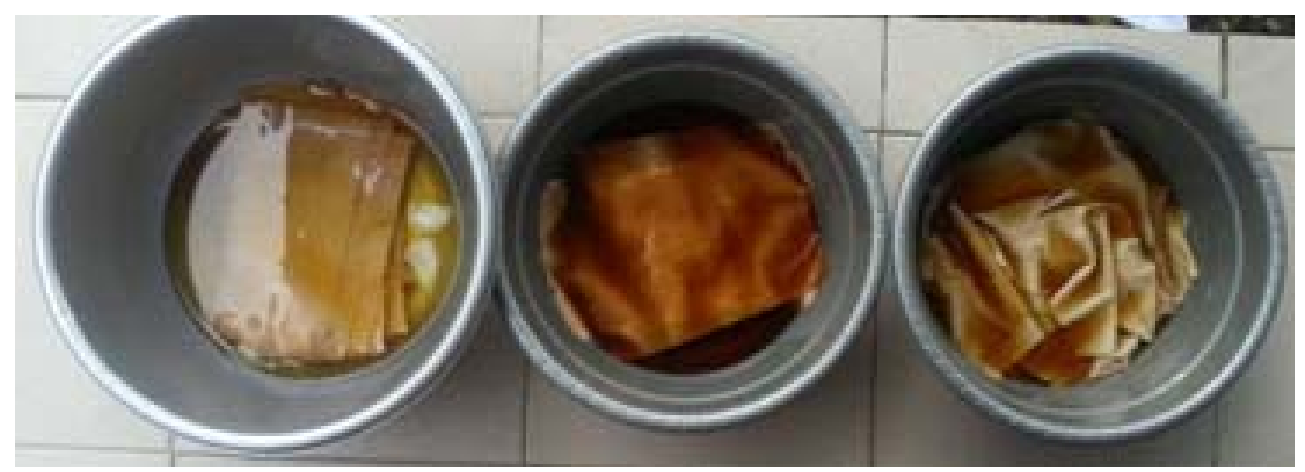

Gambar 5. Proses fiksasi 
Vol. 4, No. 2, April 2017

tabel 1. Pewarnaan Kain dengan Pewarna Secang

\begin{tabular}{|c|c|c|c|c|}
\hline NO & JENIS KAIN & $\begin{array}{c}\text { Fiksator } \\
\text { Tawas }\end{array}$ & $\begin{array}{c}\text { Fiksator Jeruk } \\
\text { Nipis }\end{array}$ & $\begin{array}{l}\text { Fiksator Bakin } \\
\text { soda }\end{array}$ \\
\hline 1. & Katun Prima & & & \\
\hline 2. & Hero/Eru & & & \\
\hline 3. & Mori & & & \\
\hline 4. & Katun Primis & & & \\
\hline 5. & Mori (Hulala) & & & \\
\hline 6. & Titoron & & & \\
\hline 7. & Katun Jepang Halus & & & \\
\hline 8 & Katun Jepang Sedang & & & \\
\hline
\end{tabular}


Dita Andansari, Mardhiyah Nadir, Eksplorasi Pewarnaan Beberapa Jenis Kain Menggunakan Pewarnaan Alami Jolawe dan Secang Dengan Fiksasi Tawas, Baking Soda dan Jeruk Nipis

Dari tabel 1 di atas dapat disimpulkan bahwa penggunaan fiksator tawas, menghasilkan tampilan warna merah muda, penggunaan fiksator jeruk nipis menghasilkan warna merah muda cenderung ke arah kecoklatan sedangkan baking soda menghasilkan warna merah muda tetapi dalam value yang rendah. Untuk tampilan mengkilat atau tidaknya, jenis kain katun Jepang Halus dan Mori (Hulala) terlihat mengkilat sesuai dengan karakter kainnya. Sedangkan kain tetoron menjadi terkesan lebih tebal.

Dari tabel 2 di samping dapat dilihat bahwa warna dapat diserap oleh semua jenis kain dengan fiksator tawas, dengan penyerapan paling sempurna terjadi pada kain katun prima dan katun primis. Sedangkan dengan fiksator jeruk nipis, warna sebagian besar tidak terserap kecuali pada jenis kain katun prima dan primis tetapi dengan value yang rendah. Untuk penggunaan fiksator baking soda, sama dengan fiksator jeruk nipis, warna hamper sebagian besar tidak terserap kecuali pada kain katun prima dan primis dengan value yang rendah.

Dengan demikian dari eksperimen pewarnaan menggunaan zat warna alami secang dan jolawe, dapat disimpulkan penggunaan fiksator tawas adalah yang paling menghasilkan penyerapan warna yang baik (kain katun prima, hero/eru, mori, katun primis, mori (hulala), titoron, katun Jepang halus (Roberto) dan katun Jepang sedang (Kenter). Untuk pewarna alami secang, penggunaan fiksator jeruk nipis dan baking soda kurang direkomendasikan kecuali memerlukan tampilan merah muda ke arah kecoklatan untuk fiksator jeruk nipis dan merah muda dengan value rendah untuk fiksator baking soda. Sedangkan penggunaan pewarna alami jolawe pada penggunaan jenis kain (katun prima, hero/eru, mori, mori hulala, tetoron KTSP, katun Jepang halus Roberto dan katun Jepang sedang Kenter) disarankan menggunakan fiksator tawas, sedangkan untuk penggunaan fiksator jeruk nipis dan baking soda tidak disarankan.

\section{Kesimpulan}

Setelah dilakukan eksperimen pewarnaan beberapa jenis kain (kain katun prima, hero/ eru, mori, katun primis, mori (hulala), titoron, katun Jepang halus (Roberto) dan katun Jepang sedang Kenter), dengan pewarna alami secang dan jolawe, maka dapat disimpulkan bahwa :

1. penggunaan fiksator tawas adalah yang paling menghasilkan penyerapan warna yang baik.

2. Untuk pewarna alami secang, penggunaan fiksator jeruk nipis dan baking soda kurang direkomendasikan kecuali memerlukan tampilan merah muda ke arah kecoklatan untuk fiksator jeruk nipis dan merah muda dengan value rendah untuk fiksator baking soda.

3. Penggunaan pewarna alami jolawe, untuk penggunaan fiksator jeruk nipis dan baking soda tidak disarankan.

\section{Saran}

1. Perlu dilakukan ekperimen pewarnaan dengan teknik jumputan untuk mengetahui hasil pewarnaan yang lebih aplikatif

2. Perlu dilakukan eksperimen dengan metode yang lebih kuantitaif sepeti grey scale, ketahanan seterika, ketahanan panas dan metode lainnya sesuai SNI. 
Vol. 4, No. 2, April 2017

Tabel 2. Pewarnaan Kain dengan Pewarna Jolawe

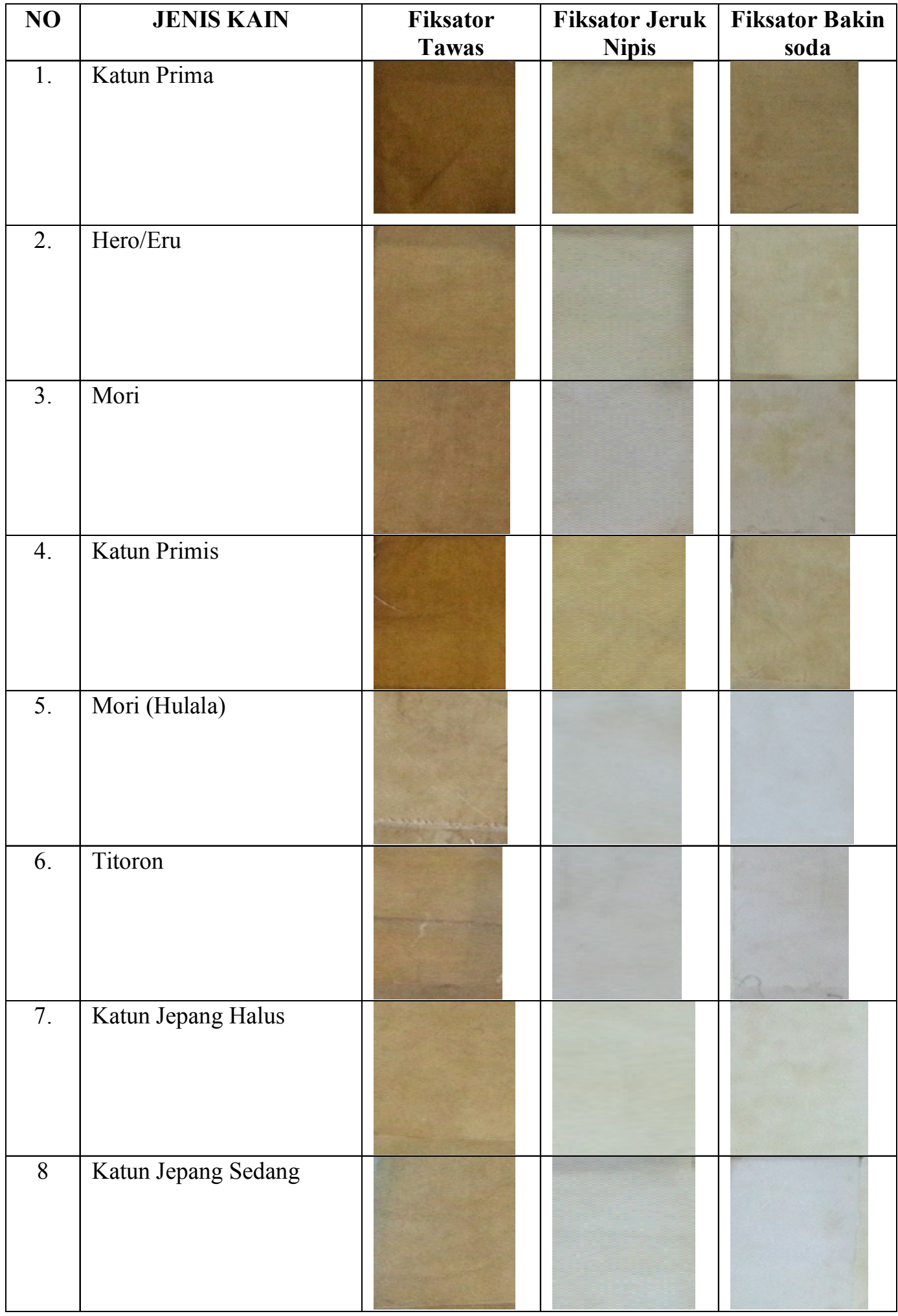


Dita Andansari, Mardhiyah Nadir, Eksplorasi Pewarnaan Beberapa Jenis Kain Menggunakan Pewarnaan Alami Jolawe dan Secang Dengan Fiksasi Tawas, Baking Soda dan Jeruk Nipis

\section{DAFTAR PUSTAKA}

Akriliyati,N. 2016. Mengenal Jenis Kain dan Pemeliharaannya. Berita Satu, Senin, 24 Oktober 2016 15:15 WIB,

Herdiana dan Khoe (2015) dalam penelitian The Dye Techniques and Material Variation. Fakultas Industri Kreatif Universitas Surabaya

Muslikhah, Riana I. Pengembangan Industri Fesyen Sebagai Industri Kreatif Unggulan Untuk Mendorong Pembangunan Ekonomi Indonesia. Fakultas Keguruan dan Ilmu Pendidikan Universitas Sebelas Maret Surakarta. Surakarta.

Sutopo. 2002. "Metodologi Penelitian Kualitatif”. Surakarta: UNS Press.

2008. Pengembangan Ekonomi Kreatif Indonesia 2025.

Departemen Perdaganagn Republik Indinesia.

2014. Mendukung Industri Periwisata. Media Indagkop

Kaltim Triwulan I. hal. 86-87. Triwulan II. hal. 18. Triwulan III. hal. 16.

Triwulan IV. hal. 9-19,42. Disperindagkop dan UMKM Provinsi Kaltim.

2015. Seminar Nasional "Inovasi dalam Desain dan Teknologi”

IDeaTech 2015 Tie Dye. Tribun Jabar, Yuk Kenali Jenis-jenis kain katun yang dijual di pasaran, Kamis 24 Agustus 2017 17:45 WIB,

http://elib.pdii.lipi.go.id 